\title{
ANALISIS RANTAI NILAI DAN MATRIKS STRATEGI PADA PENGEMBANGAN SOP PT. GSG
}

\author{
IBK. Bayangkara \\ Untag Surabaya \\ bhayangkara@untag-sby.ac.id
}

\begin{tabular}{l|l|l} 
Received: August & Accepted: October & Published: December
\end{tabular}

\begin{abstract}
This study aims to analyze the internal value chain and assess the effectiveness of the implementation of the Mc Farlan Strategic Matrix in the development of PT Graha Sarana Gresik SOPs. Using a case study approach, the researcher interviewed 59 respondents including the Board of Directors to the Head of Affairs and observed the relationship between one part and another in the supplier-customer relationship. The study found that there is a series of value chains in the relationship between divisions that can increase competitive advantage. Integrating this value chain in the design of SOPs can be an effective and efficient operational guideline. Another finding, the company has a high dependence on Information Systems (SOP), but at a low level of urgency in the Mc Farlan Strategic Matrix is included in the Factory category. The results of this study become a reference for companies in the preparation of SOPs to integrate their operations effectively and efficiently.
\end{abstract}

Keywords: value chain, SOP, integration, effective, efficient

\section{ABSTRAK}

Penelitian ini bertujuan untuk menganalisis rantai nilai internal (internal value chain) dan menilai efektifitas penerapan Mc Farlan Strategic Matrix pada pengembangan SOP PT Graha Sarana Gresik. Menggunakan pendekatan studi kasus, peneliti mewawancarai 59 responden meliputi Direksi sampai dengan kepala Urusan dan melakukan observasi keterhubungan satu bagian dengan bagian yang lain dalam hubungan pemasok - pelanggan. Penelitian menemukan, terdapat rangkaian rantai nilai dalam hubungan antar Divisiyang dapat meningkatkan keunggulan bersaing. Mengintegrasikan rantai nilai ini dalam rancangan SOP dapat menjadi pedoman operasional yang efektif dan efisien. Temuan lain, perusahaan memiliki ketergantungan yang tinggi terhadap Sistem Informasi (SOP), tetapi pada tingkat urgenitas yang rendah dalam Mc Farlan Strategic Matrix termasuk dalam kategori Factory. Hasil penelitian ini menjadi referensi bagi perusahaan dalam penyusunan SOP untuk mengintegrasikan operasionalnya secara efektif dan efisien.

Kata kunci : rantai nilai, SOP, integrasi, efektif, efisien

\section{PENDAHULUAN}

Efektivitas tata Kelola organisasi (perusahaan) membutuhkan standar sebagai pedoman bertindak. Perusahaan tidak cukup hanya memiliki uraian pekerjaan (job description), tetapi juga harus memiliki prosedur operasional standar (standard operating procedure/SOP) untuk mencapai tata kelola yang efektif dan efisien. Uraian pekerjaan menggambarkan apa yang seharusnya dikerjakan oleh setiap individu sesuai dengan fungsi yang dijalankan agar bisa berkontribusi maksimal pada perusahaan. Setiap uraian pekerjaan mendokumentasikan tugas, tanggung jawab dan wewenang dari setiap individu dan laporan 
yang harus disampaikan kepada atasannya sebagai wujud kinerja dari setiap pelaksanaan tugas dan tanggung jawabnya.

Jika uraian pekerjaan merincikan apa yang harus dikerjakan seorang karyawan, SOP memberikan panduan bagaimana suatu pekerjaan dilakukan agar tujuan dari pelaksanaan tugas-tugas tersebut tercapai secara efektif dan efisien. Efisiensi adalah ukuran dari proses (Bayangkara, 2019:16), maka suatu SOP harus bisa mengoptimalkan penggunaan sumber daya, dimana aktivitas-aktivitas yang bersifat tumpang tindih secara maksimal bisa dihindari, karena merupakan sumber pemborosan (non value added activity). Sedangkan efektivitas adalah merupakan ukuran dari output (pencapaian tujuan), maka setiap aktivitas harus mampu mencapai tujuannya (Bayangkara,2019:17). Pengelolaan keterhubungan antar departemen/divisi dalam operasional dan layanan kepada pelanggan menjadi suatu rangkaian proses yang mengintegrasikan peran dan fungsi masing-masing berfokus pada kepuasan pelanggan, merupakan wujud komitmen dan tugas manajemen dalam mengoptimalkan penggunaan sumber daya dalam keunggulan bersaingnya. Hansen \& Mowen menyebut ini sebagai rantai nilai internal (Hansen \& Mowen, 2007)

Kesadaran yang semakin meningkat bahwa keunggulan bersaing bisa tercapai jika tata kelola perusahaan berjalan secara efektif dan efisien, mendorong semakin meningkatnya kebutuhan perusahaan untuk memiliki SOP yang sesuai dengan proses bisnisnya. Perusahaan berusaha memberikan kepastian kepada setiap karyawan dalam bentuk pedoman bertindak dan mendasarkan pegendaliannya pada SOP ini.

Penelitian ini bertujuan untuk menganalisis keterhubungan antara satu divisi dengan divisi yang lain dan aktivitas-aktivitas yang ada didalamnya, dalam memberikan pelayanan unggul kepada pelanggan dan memetakan peran SOP dalam memberikan pedoman aktivitas sebagai bagian dari strategi keunggulan bersaing perusahaan. Hasil analisis dan pemetaan ini menjadi rekomendasi dan referensi utama dalam penyusunan SOP yang mengintegrasikan operasional perusahaan agar berjalan secara Ekonomis, efisien dan efektif dalam pencapaian tujuannya. Dengan design kualitatif, penelitian ini menggunakan pendekatan studi kasus, dilaksanakan pada PT. Graha Sarana Gresik, sebuah perusahaan yan bergerak pada bidang perdagangan, pembangunan perumahaan, pengelolaan perkantoran persewaan dan bidang restoran.

\section{TINJAUAN PUST AKA}

\section{Rantai Nilai (value chain)}

Porter menggambarkan rantai nilai (value chain) sebagai proses atau aktivitas internal yang dilakukan perusahaan untuk merancang, memproduksi, memasarkan, mengirimkan, dan mendukung produknya (IMA, 1996). Lebih lanjut Porter memperkenalkan dua kategori aktivitas penting dalam rangkaian rantai nilai perusahaan, yaitu aktivitas utama (prime activities) dan aktivitas pendukung (supporting activities). Aktivitas utama merupakan aktivitas-aktivitas yang terlibat langsung dalam mengubah input menjadi output, pengiriman dan dukungan purna jual. Aktivitas utama berhubungan langsung dengan penciptaan fisik, penjualan, pemeliharaan dan dukungan produk atau layanan, terdiri dari

1. Logistik masuk - adalah seluruh proses yang terkait dengan penerimaan, penyimpanan, dan mendistribusikan input secara internal. Hubungan dengan pemasok adalah faktor kunci dalam menciptakan nilai.

2. Operasi - merupakan kegiatan transformasi yang mengubah input menjadi output yang dijual kepada pelanggan. Di sini, sistem operasional menciptakan nilai.

3. Logistik keluar - Aktivitas ini mengirimkan produk atau layanan kepada pelanggan. Ini adalah hal-hal seperti pengumpulan, penyimpanan, dan sistem distribusi, baik internal maupun eksternal organisasi.

4. Pemasaran dan penjualan - merupakan proses yang digunakan untuk membujuk klien agar membeli bukan dari pesaing.

5. Layanan - merupakan aktivitas yang berkaitan dengan mempertahankan nilai produk atau layanan kepada pelanggan setelah dibeli. 
Aktivitas Pendukung, mendukung fungsi-fungsi utama di atas. Setiap aktivitas pendukung (sekunder), dapat memainkan peran dalam setiap aktivitas primer. Sebagai contoh, pengadaan mendukung operasi dengan kegiatan tertentu, tetapi juga mendukung pemasaran dan penjualan dengan kegiatan lainnya. Aktivitas pendukung terdiri dari (Porter 1985) :

1. Pengadaan (pembelian) - Aktivitas organisasi untuk mendapatkan sumber dayanya, termasuk menemukan vendor dan menegosiasikan harga terbaik.

2. Manajemen sumber daya manusia - aktivitas perusahaan dalam memenuhi kebutuhan SDM : merekrut, mempekerjakan, melatih, memotivasi, menghargai, dan mempertahankan pekerjanya. Manusia adalah sumber nilai yang signifikan, jadi bisnis dapat menciptakan keuntungan yang jelas dengan praktik SDM yang baik.

3. Pengembangan teknologi - berkaitan dengan pengelolaan dan pemrosesan informasi, serta melindungi basis pengetahuan perusahaan. Meminimalkan biaya teknologi informasi, mengikuti perkembangan teknologi, dan mempertahankan keunggulan teknis adalah sumber penciptaan nilai.

4. Infrastruktur - Ini adalah sistem pendukung perusahaan, dan fungsi yang memungkinkan untuk mempertahankan operasi sehari-hari. Akuntansi, hukum, administrasi, dan umum.

Hubungan antara aktivitas utama dan aktivitas pendukung dalam rantai nilai Porter, digambarkan pada peraga 1 dibawah ini :

\section{Gambar 1 Model Rantai nilai Porter}

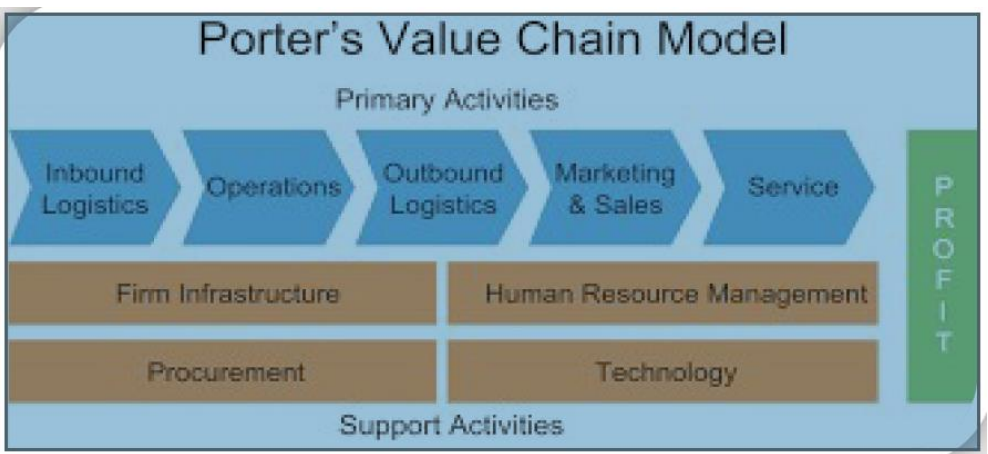

Shank dan Govindarajan (1993) menggambarkan rantai nilai dalam istilah yang lebih luas, menyatakan bahwa "rantai nilai adalah aktivitas penciptaan nilai mulai dari sumber bahan baku dasar dari pemasok komponen hingga produk dikirimkan ke tangan konsumen akhir." Deskripsi ini memandang perusahaan sebagai bagian dari keseluruhan rantai proses penciptaan nilai.

\section{Proses Rantai Nilai Porter}

Untuk mengidentifikasi dan memahami rantai nilai perusahaan, Porter merekomendasikan langkah-langkah berikut :

\section{Langkah 1 - Identifikasi sub kegiatan untuk setiap kegiatan utama}

Untuk setiap aktivitas utama, tentukan sub aktivitas spesifik mana yang menciptakan nilai. Ada tiga jenis sub kegiatan:

a. Aktivitas langsung menciptakan nilai dengan sendirinya. Misalnya, dalam pemasaran penerbit buku dan aktivitas penjualan, sub aktivitas langsung meliputi melakukan kunjungan penjualan ke toko buku, periklanan, dan penjualan online.

b. Kegiatan tidak langsung memungkinkan kegiatan langsung berjalan dengan lancar. Untuk penjualan penerbit buku dan kegiatan pemasaran, sub kegiatan tidak langsung meliputi pengelolaan tenaga penjualan dan menjaga catatan pelanggan. 
c. Kegiatan jaminan kualitas memastikan bahwa kegiatan langsung dan tidak langsung memenuhi standar. Untuk aktivitas penjualan dan pemasaran penerbit buku, ini mungkin termasuk: mengoreksi dan mengedit iklan.

\section{Langkah 2 - Identifikasi sub aktivitas untuk setiap aktivitas pendukung.}

Untuk masing-masing Manajemen Sumber Daya Manusia, Pengembangan Teknologi dan Pengadaan mendukung aktivitas, menentukan sub aktivitas yang menciptakan nilai dalam setiap aktivitas utama. Misalnya, pertimbangkan bagaimana manajemen sumber daya manusia menambah nilai logistik masuk, operasi, logistik keluar, dan sebagainya. Seperti pada Langkah 1, cari langsung, tidak langsung, dan kualitas sub kegiatan penjaminan. Kemudian, identifikasi berbagai sub kegiatan yang menciptakan nilai dalam infrastruktur perusahaan. Ini umumnya akan bersifat lintas fungsi, daripada spesifik untuk setiap aktivitas utama. Sekali lagi, cari jaminan langsung, tidak langsung, dan kualitas kegiatan.

\section{Langkah 3 - Identifikasi hubungan (tautan)}

Temukan hubungan antara semua aktivitas nilai yang telah diidentifikasi. Ini akan memakan waktu, tetapi tautannya adalah kunci untuk meningkatkan keunggulan bersaing dari kerangka rantai nilai. Misalnya, ada hubungan antara mengembangkan tenaga penjualan (investasi SDM) dan volume penjualan. Ada tautan lain antara waktu penyelesaian pesanan, dan panggilan telepon layanan dari pelanggan yang menunggu pengiriman.

\section{Langkah 4 - Cari peluang untuk meningkatkan nilai}

Tinjau setiap sub kegiatan dan tautan yang telah diidentifikasi, dan pikirkan bagaimana kegiatan terseut bisa diubah atau ditingkatkan untuk memaksimalkan nilai.

\section{Matriks Strategi Sistem Informasi}

System informasi mengelola proses, administrasi, pelaporan operasional organisasi dan menyediakan informasi yang lengkap, akurat dan tepat waktu untuk pengambilan keputusan. System informarsi terdiri dari prosedur-prosedur (sub system) yang terintegrasi dalam satu kesatuan menjadi prosedur standar operasional (standar operating procedure/SOP) yang menjadi pedoman bertindak bagi setiap individu/kelompok dalam organisasi.

Integrasi sistem informasi merupakan salah satu konsep kunci dari sistem informasi manajemen (Veronika, 2015). Berbagai sistem dapat saling berhubungan satu dengan yang lain dengan berbagai cara yang sesuai dengan keperluan integrasinya. Semakin tinggi tingkat integrasi system informasi, semakin tinggi manfaat yang bisa diperoleh dari penerapan system tersebut.

Strategi Sistem Informasi adalah proses identifikasi portofolio aplikasi yang selaras dengan strategi perusahaan untuk menciptakan keunggulan bersaing. Secara prinsip, peranan sebuah sistem informasi dapat dilihat dari dua perspektif utama, yaitu (1) seberapa besar ketergantungan perusahaan terhadap sistem dan teknologi informasi; dan (2) seberapa besar potensi sistem informasi dan teknologi untuk dapat memberikan keunggulan bersaing bagi perusahaan. Warren McFarlan (1983) mengelompokkan tingkat ketergantungan dan urgenitas system informsi dalam keunggulan bersaing perusahaan dalam empat diagram yaitu :

\section{1) Strategis}

system informasi yang secara signifikan memiliki nilai strategis bagi perusahaan. Bagaimanapun, jelas bahwa sistem informasi sangat penting untuk kelangsungan hidup dan kesuksesan perusahaan 


\section{2) Turnaround}

System ini adalah yang secara langsung dapat memberikankeunggulan kompetitif kepada perusahaan yang memilikinya, namun secara prinsip perusahaan tersebut tidak tergantung eksistensinya terhadap system Informasi yang bersangktun.

\section{3) Factory}

Jenis system ketiga adalah teknologi informasi yang tidak secara langsung memberikan keunggulan kompetitif kepada perusahaan, namun keberadaannya mutlak diperlukan.

\section{4) Support}

system informasi atau teknologi informasi yang hanya berfungsi sebagai penunjang perusahaan (kinerja perusahaan tidak bergantung kepada peranan teknologi informasi) dan tidak memiliki potensi yang besar dalam memberikan keunggulan bersaing perusahaan

\section{Gambar 2 : Posisi sistem informasi di berbagai jenis perusahaan}

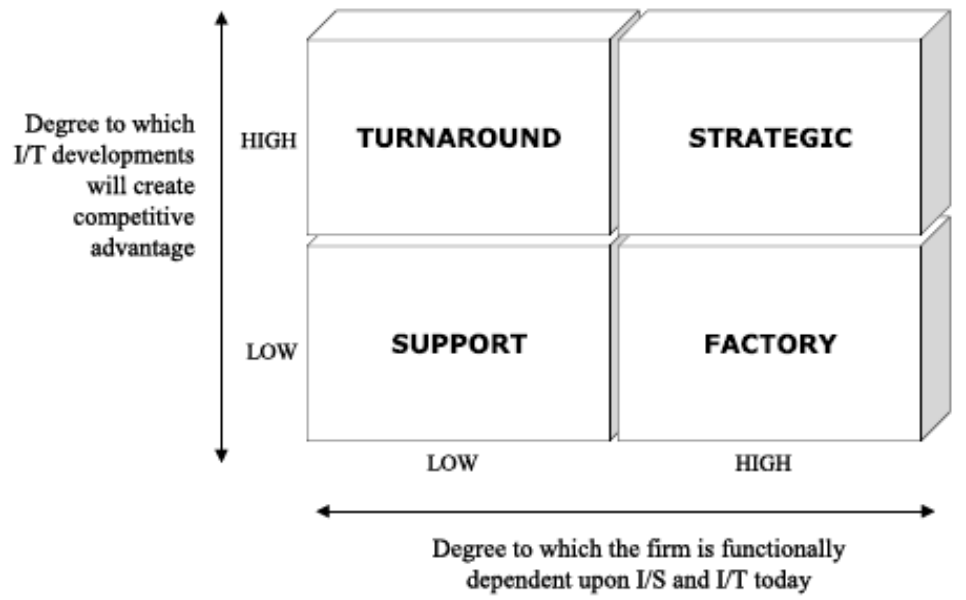

Sumber : McFarlan (1983)

\section{Standar Operating Procedure}

SOP atau prosedur operasional standar merupakan instruksi yang memiliki kekuatan sebagai suatu petunjuk pekerjaan (Rifka, 2017). Hal ini mencakup hal-hal dari operasi yang memiliki suatu prosedur pasti atau terstandarisasi tanpa kehilangan efektivitasnya. Setiap sistem manajemen yang berkualitas baik selalu didasari oleh SOP sebagai pedoman dalam melaksanakan pekerjaan rutin. Standard Operating Procedures (SOP) yang merupakan dokumen proses, menjelaskan secara rinci cara operator harus melakukan operasi tertentu. SOP adalah salah satu dari banyak dokumen proses yang diperlukan untuk operasi yang konsisten dari proses yang diberikan, dengan dokumen lain yang melibatkan diagram alur proses, spesifikasi material, dan sebagainya. SOP menjelaskan tentang : apa tujuan dari SOP (Purpose), apa penerapan dan penggunaan SOP (Scope)?, siapa yang akan melakukan tugas (Responsibility), siapa yang akan memastikan pelaksanaan prosedur (Accountability) dan bagaimana tugas akan dilakukan (Procedure) (Akyar, 2012).

Mengapa SOP penting?. SOP adalah petunjuk langkah-demi-langkah tertulis tentang cara menjalankan prosedur dengan benar. SOP dimaksudkan untuk memastikan konsistensi, akurasi dan kualitas data (WHO, 2011). SOP menyelaraskan praktik, mengurangi kesalahan pengguna, dan dapat digunakan sebagai alat pelatihan. Tujuan dari SOP adalah untuk menjangkau operasi dengan benar dan selalu dengan cara yang sama. Sebuah SOP harus 
tersedia di tempat pekerjaan dilakukan. SOP membantu kemajuan penerapan proses dan prosedur secara konstan sehingga bahkan ketika ada perubahan personel, organisasi menghindari inkonsistensi dan risiko keselamatan (Frank, D. 2010).

Integrasi operasional menjadi sebuah rangkaian proses, menyambungkan saling keterhubungan antara satu Bagian/Divisi dengan Bagian/Divisi lain dalam mewujudkan produk/layanan yang sesuai dengan persyaratan pelanggan (customer requirement). Ini adalah bentuk pengelolaan rantai nilai internal, Rantai nilai internal adalah serangkaian aktivitas yang diperlukan untuk merancang, mengembangkan, memproduksi, memasarkan, dan mengirimkan produk dan layanan kepada pelanggan (Hansen \& Mowen, 2007; 11). Wujud komitmen manajemen dalam mengelola rantai nilai internalnya dituangkan dalam suatu SOP yang didasari kesadaran hubungan pemasok - pelanggan antara satu bagian dengan bagian lainnya. Dasar philosophinya, dalam setiap hubungan, setiap pemasok harus memuaskan pelanggannya.

Memiliki SOP bagi perusahaan adalah menyediakan alat pengendalian yang bisa menghindarkan terjadinya penyalah gunaan asset oleh oknum perusahaan, tercapainya operasional yang fleksibel, efektif dan efisien. Lebih jauh Schmidt and Pierce (2016) menguraikan lebih rinci manfaat dari SOP, meliputi :

1. SOP dapat digunakan sebagai seperangkat 'Standar kinerja', yang membantu memastikan bahwa tugas yang sama dilakukan secara konsisten oleh semua pekerja. Pada saat yang sama berfungsi untuk menentukan tingkat kinerja yang dapat diterima untuk suatu tugas.

2. SOP adalah kumpulan Instruksi, menginstruksikan pekerja tentang bagaimana menyelesaikan tugas secara efektif, efisien dan konsisten.

3. SOP dapat digunakan sebagai Referensi. SOP memiliki informasi rinci tentang langkahlangkah yang terlibat dalam proses tertentu, sehingga dapat dirujuk jika terjadi ambiguitas. SOP juga menyediakan daftar periksa hemat waktu untuk memastikan bahwa setiap langkah diikuti dengan benar.

4. SOP dapat digunakan untuk Review. Mereka berfungsi sebagai catatan dasar tentang bagaimana tugas dilakukan yang sangat penting untuk kesuksesan

5. Untuk menyediakan semua orang dengan semua informasi keselamatan, kesehatan, lingkungan dan operasional yang diperlukan untuk melakukan pekerjaan dengan benar.

6. SOP dan CQA dalam Kesehatan-Konsep kunci dalam CQA (Continuous Quality Approval) yaitu pengurangan variasi dan peningkatan proses memerlukan standar sebagai dasar.

7. SOP menentukan langkah-langkah pekerjaan yang membantu standarisasi kualitas layanan.

\section{METODE PENELITIAN}

Mengunakan design penelitian kualitatif, penelitian ini menerapkan pendekatan studi kasus. Peneliti mewawancarai secara mendalam Direksi, seluruh Kepala Divisi (manajer), Kepala Seksi dan Kepala Urusan dengan keseluruhan responden 59 orang. Disamping itu, peneliti juga melakukan observasi, mengamati keseluruhan proses yang berjalan dan mendokumentasikan formulir dan laporan yang digunakan/dibuat selama ini. Perancangan prosedur berpedoman pada proses bisnis perusahaan, integrasi operasional melalui pengelolaan keterhubungan antar bagian dalam rantai nilai internal (internal value chain).

Hasil wawancara dan observasi dianalisis berdasarkan proses rantai nilai Porter, untuk menentukan rangkaian rantainilai internal pada setiap aktivitas yang terhubung dalam operasional perusahaan. Kemudian untuk menentukan posisi strategis Sistem Informasi (SOP) bagi perusahaan, peneliti memetakan tingkat ketergantungan dan urgensi perusahaan terhadap SOP dalam mencapai keunggulan bersaingnya berdasarkan matrik Warren McFarlan. 


\section{Analisis Keterhubungan antar Divisi dalam Operasional PT. Graha Sarana Gresik}

Bisnis utama PT. Graha Sarana Gresik (GSG) adalah perdagangan. Perusahaan yang merupakan bagian dari Group PT. Petrokimia Gresik ini merupakan pemasok bahan baku dan chemical untuk produksi pupuk yang merupakan produk utama dari PT. Petrokimia Gresik. Disamping itu GSG juga menjalankan bisnis persewaan dan pengelolaan gudang-gudang penyangga (untuk mendistribusikan pupuk hasil produksi PT. Petrokimia Gresik ke seluruh Indonesia), usaha pengembang perumahan, Resto dan café. Operasional GSG dikelola dalam divisi-divisi, meliputi : 1) divisi perdagangan dan jasa, 2) divisi pergudangan 3) divisi perumahan, 4) divisi property dan perkantoran, 5) divisi SDM dan Umum, 6) divisi Administrasi dan keuangan, 7) divisi pengadaan dan 8) divisi SPI.

\section{Proses Rantai Nilai Porter}

Porter merekomendasikan empat Langkah berikut dalam proses rantai nilai, meliputi :

\section{Mengidentifikasi sub kegiatan untuk setiap kegiatan utama}

Empat aktivitas utama GSG dalam memenuhi kebutuhan pelaggan dan menjadi sumber keunggulan bersaing perusahaan meliputi : 1) Penjualan barang dan Jasa, 2) Persewaan dan Jasa Operasional Gudang, 3) Penjualan dan pembangunan Perumahan dan 4) Layanan Perkantoran.

\section{1) Aktivitas langsung}

Sub-sub aktivitas yang secara langsung terlibat dalam penciptaan nilai untuk aktivitas-aktivitas utama ini meliputi :

1) Aktivitas perdagangan Umum, jasa persewaan dan pergudangan, meliputi :
a) Kunjungan pelanggan untuk mendapatkan informasi kebutuhan pelanggan, spesifikasi, kuantitas dan waktu penyerahannya
b) Mengomunikasikan kebutuhan pelanggan dengan pemasok mitra untuk mendapatkan dukungan pemasok
c) Penyerahan barang tepat waktu

2) Persewaan dan Jasa Operasional Gudang

a) Pemenuhan spesifikasi dan penyerahan gudang tepat waktu

b) Pelayanan administrasi dan pelaporan operasional gudang yang akurat dan tepat waktu

3) Aktivitas penjualan dan pembangunan perumahan, meliputi :

a) Mengunjungi calon pelanggan untuk menawarkan rumah dengan berbagai fasilitas yang termasuk didalamnya

b) Menunjuk kontraktor rekanan untuk membangun rumah sesuai dengan pesanan pelanggan

c) Pelayanan penyelesaian dokumen kepemilikan rumah

4) Aktivitas Layanan Perkantoran, meliputi :

a) Melakukan pemeliharaan (perawatan) fasilitas perkantoran sesuai dengan standar yang telah ditetapkan

b) Memenuhi layanan tambahan pelanggan sesuai dengan permintaannya

\section{2) Aktivitas Tidak Langsung}

Sub-sub aktivitas yang secara tidak langsung berperan dalam mendukung agar aktivitas langsung berjalan dengan lancer meliputi :

1) Pemberdayaan tenaga penjualan dan layanan pemeliharaan perkantoran

2) Memelihara hubungan baik dengan pemasok mitra

3) Layanan penyelesaian complain pelanggan dalam waktu singkat 


\section{3) Aktivitas Jaminan Kualitas}

Sub-sub aktivitas memastikan bahwa kegiatan langsung dan tidak langsung berjalan sesuai dengan standar yang telah ditentukan. Sub-sub aktivitas ini meliputi :
a) Pengaturan jadwal dengan pemasok untuk pengiriman barang kepada pelanggan
b) Inspeksi kualitas dan kuantitas barang ditempat pemasok sebelum barang dikirim kepada penggan
c) Pengawasan pembagunan rumah agar sesuai dengan spesifikasi yang disepakati dengan pelanggan
d) Inspeksi hasil layanan perkantoran yang diberikan kepada pelanggan

\section{Langkah 2 - Identifikasi sub aktivitas untuk setiap aktivitas pendukung.}

Aktivitas pendukung dalam operasionl GSG terdiri dari : 1) Manajemen Sumber Daya Manusia, 2) Pengadaan dan pengembangan, 3) administrasi dan keuangan dan 4) Pengawasan Intern. Setiap aktivitas pendukung memiliki peran dalam mendorong dan memfasilitasi aktivitas utama dalam proses penciptaan nilai dan keunggulan bersaing GSG.

Manajemen sumber daya manusia, fokus pada penyediaan kapasitas SDM sesuai dengan kebutuhan. Kapasitas SDM tidak cukup hanya direpresentasikan oleh jumlah orang yang harus dipekerjakan tetapi yang lebih penting adalah Bagaimana setiap insan dalam perusahaan memiliki kemampuan (kompetensi) untuk berkontribusi pada penciptaan nilai. Berbagai program penglolaan SDM diselenggarakan seperti pelatihan dan pengembangan karywan, pemberdayaan, perencanaan dan pengembangan karier, adalah semata-mata untk meningkatkan kontribusi SDM pada keunggulan bersaing perusahaan.

Fungsi pengadaan merencnakan dan mengadakan seluruh barang, baik yang akan dijual kembali (sesuai pesanan pelanggan) maupun untuk digunakan sendiri, sampai dengan barang tersebut siap untuk diserahkan/digunakan. Untuk meyakinkan bahwa opeasional berjalan sesuai dengan strategi keunggulan bersaing perusahaan, fungsi pengendalian intern (satuan pengawas intern) memastikan bahwa setiap aktivitas penciptaan nilai berjalan secara efektif dan efisien.

\section{Langkah 3 - Identifikasi hubungan (tautan)}

Dukungan sub-sub aktivitas pendukung pada aktivitas utama merupakan suatu rangkaian aktivitas dalam proses penciptaan nilai. Pelatihan dan pengembangan keterampilan dan kempauan tenaga penjual, meningkatkan kemampuannya untuk memahami kebutuhan atau persyaratan pelanggan kemudian mengomunikasikan kepentingan tersebut dalam proses internal pemenuhan kebutuhan dan kepuasan pelanggan, mendorong peningkatan volume penjualan perusahaan.

Demikian halnya dukungan fungsi pengadaan pada peningkatan kepuasan pelanggan. Perencanaan pengadaan, yang mengintegrasikan kebutuhan ketersediaan pasokan pada pelanggan dengan Jadwal pengiriman dari pemasok, dapat meningkatkan akurasi pemenuhan persyaratan pelanggan terkait dengan ketepatan waktu, tanpa membutuhkan tempat penyimpanan material, karena material dikirim langsung kepada pemasok pada saat dibutuhkan.

Fungsi penganggaran (rencana bisnis) membantu perusahaan dalam menghitung harga pokok dan harga jual produk yang akan diserahkan kepada pelanggan. Analisis efisiensi dan penerapan manajemen risiko pada penganggaran, mengarahkan rencana harga pokok tersusun berdasarkan pada basis risiko terkendali dan efisiensi tinggi. Hal ini sangat membantu perusahaan dalam memaksimalkan nilai pelanggan melalui peningkatan manfaat (nilai) yang bisa dinikmati, atau melalui penurunan pengorbanannya atau bahkan melalui kedua-duanya, penurunan pengorbanan bersamaan dengan peningkatan manfaat yang bisa diperoleh. 


\section{Langkah 4 - Cari peluang untuk meningkatkan nilai}

Integrasi sub-sub system dalam rangkaian system (SOP) memungkinkan untuk memangkas atau mengeliminasi aktivitas-aktivitas yang berulang tanpa memberi manfaat (tumpang tindih) dalam operasional perusahaan, karena aktivitas-aktivitas tersebut merupakan aktivitas tidak bernilai tambah. Integrasi ini adalah bagian dari bentuk menyambungkan rantai nilai antara satu bagian/divisi dengan bagian/divisi yang lain dalam keseluruhan operasional perusahaan yang dituangkan dalam satu paket SOP.

\section{Matriks Strategi Sistem Informasi}

Peneliti menguji tingkat ketergantungan dan urgenitas perusahaan terhadap SOP sesuai dengan penilaian strategis system informasi Mc Farlan. Tingkat ketergantungan operasional PT. Graha Sarana Gresik terhadap ketersediaan SOP termasuk dalam kategori tinggi, karena keberadaan SOP dapat memberikan kepastian bagi seluruh insan dalam perusahaan dalam menjalankan aktivitasnya. Disamping itu, SOP juga dapat menjadi pedoman dalam operasional perusahaan yang aman dan fleksibel. Dari sudut pandang tingkat urgenitas (seberapa besar potensi system informasi dan teknologi untuk dapat memberikan keuntungan kompetitif), peneliti menemukan bahwa keberadaan SOP belum secara langsung dapat meningkatkan keunggulan bersaing perusahaan dan teridentikasi dalam tingkat urgenitas yang rendah, seperti digambarkan pada gambar 2. berikut ini :

\section{Gambar 2 : Posisi Strategis SOP pada PT. Graha Sarana Gresik}

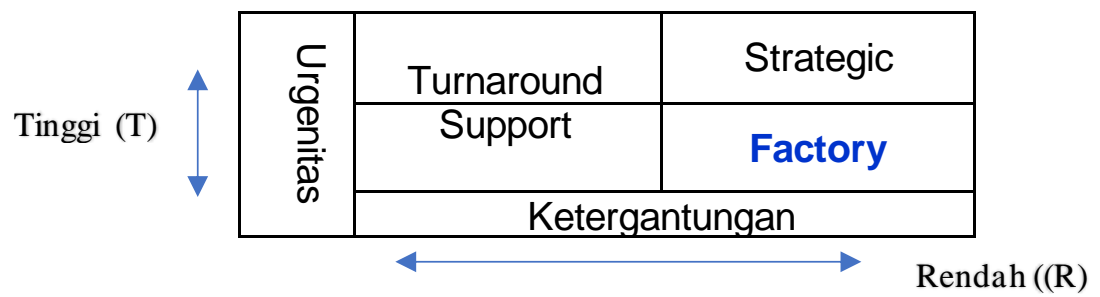

Menggunakan pendekatan (1) ketergantungan perusahaan terhadap sistem dan teknologi informasi; dan (2) potensi (urgenitas) sistem informasi dan teknologi dalam memberikan keunggulan bersaing bagi perusahaan dalam kerangka hubungan rantai nilai Porter, penulis memetakan peran Sistem informasi terhadap keunggulan bersaing perusahaan pada objek penelitian, seperti disajikan pada table 1 dibawah ini :

Tabel 1 : Tingkat Ketergantungan dan Urgenitas System Informsi, T = Tinggi; R = Rendah

\begin{tabular}{|c|c|c|c|c|c|c|}
\hline \multirow{3}{*}{ No } & \multirow{3}{*}{$\begin{array}{c}\text { Rantai } \\
\text { Aktivitas }\end{array}$} & \multirow{3}{*}{ Kebutuhan Sistem Informasi } & \multicolumn{4}{|c|}{$\begin{array}{c}\text { Tingkat Ketergantungan } \\
\text { dan Urgenitas System } \\
\text { Informsi }\end{array}$} \\
\hline & & & \multicolumn{2}{|c|}{$\begin{array}{c}\text { Ketergantun } \\
\text { gan }\end{array}$} & \multicolumn{2}{|c|}{ Urgenitas } \\
\hline & & & $\mathrm{T}$ & $\mathrm{R}$ & $\bar{T}$ & $\mathrm{R}$ \\
\hline 1 & $\begin{array}{l}\text { Penjualan } \\
\text { Bahan Baku } \\
\text { dan Chemical }\end{array}$ & $\begin{array}{l}\text { Sistem informasi penjualan yang } \\
\text { mengintegrasikan prosedur-prosedur untuk } \\
: \text { a. Memastikan ketersediaan bahan baku } \\
\text { a. dan chemical dan dukungan pemasok } \\
\text { b. Mengikuti tender } \\
\text { c. Penanganan dan pengiriman bahan } \\
\text { baku dan chemical }\end{array}$ & $\checkmark$ & & & $\checkmark$ \\
\hline
\end{tabular}




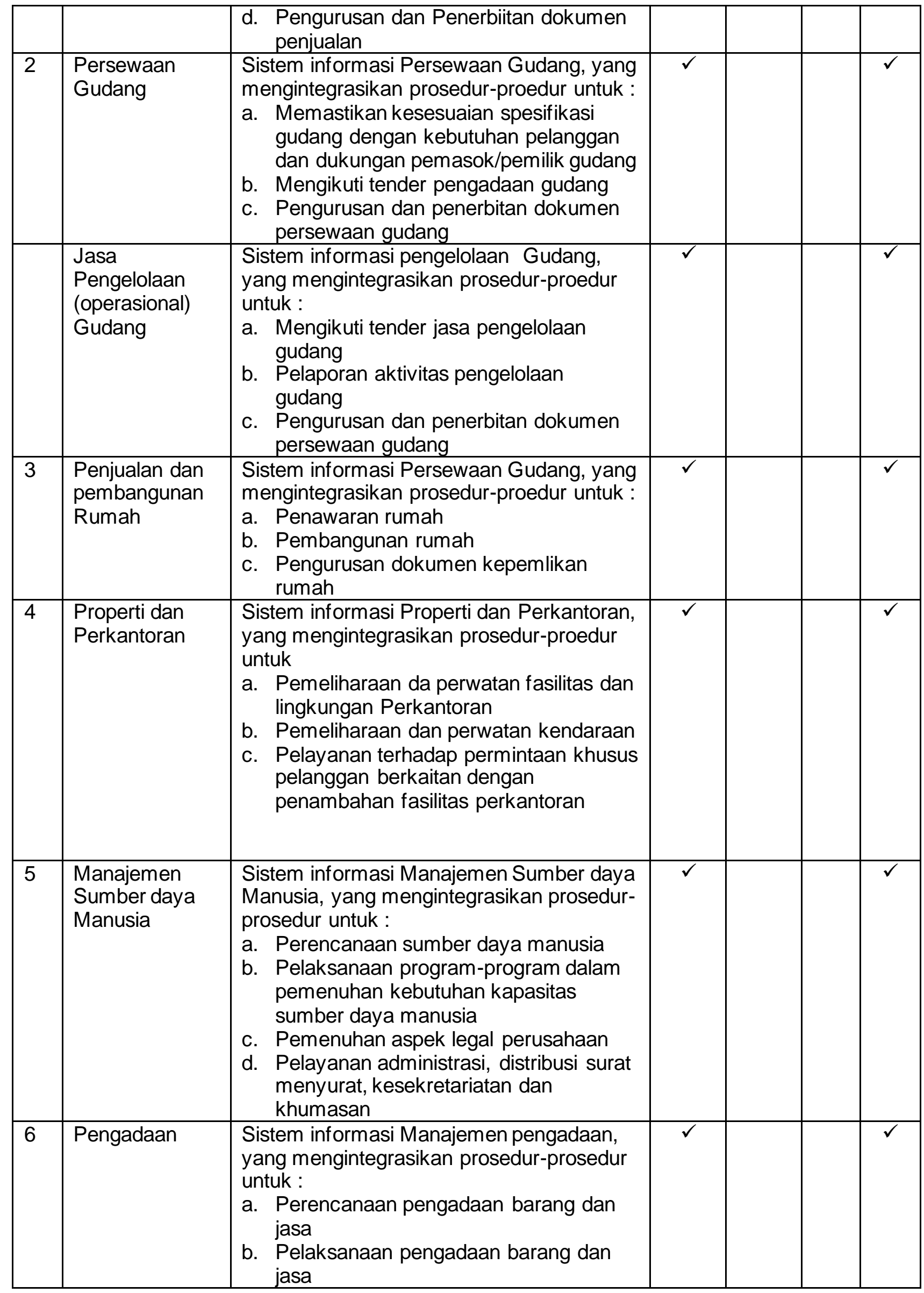




\begin{tabular}{|l|l|l|l|l|l|l|}
\hline & & $\begin{array}{l}\text { C. Pengiriman barang/jasa pesanan } \\
\text { pelanggan }\end{array}$ & & & \\
\hline 7 & $\begin{array}{l}\text { Administrasi } \\
\text { dan Keuangan }\end{array}$ & $\begin{array}{l}\text { Sistem informasi administrasi dan } \\
\text { keuangan, yang mengintegrasikan } \\
\text { prosedur-prosedur untuk : } \\
\text { a. Penyusunan RKAP Perusahaan } \\
\text { b. Pencatatan transaksi dan pelaporan } \\
\text { keuangan perusahaan } \\
\text { c. Pemenuhan kewajiban perpajakan } \\
\text { perusahaan }\end{array}$ & $\checkmark$ & & \\
\hline 8 & $\begin{array}{l}\text { Satuan } \\
\text { Pengawas } \\
\text { intern }\end{array}$ & $\begin{array}{l}\text { Sistem informasi pengendalian internal } \\
\text { perusahaan, yang mengintegrasikan } \\
\text { prosedur-prosedur : } \\
\text { a. Audit operasional perusahaan } \\
\text { b. Audit administrasi } \\
\text { c. Keselamatan dan Kesehatan kerja }\end{array}$ & $\checkmark$ & & & $\checkmark$ \\
\hline
\end{tabular}

\section{PENUTUP}

Terdapat rangkaian rantai nilai internal dari hubungan satu divisi dengan divisi yang lain, membentuk keunggulan bersaing perusahaan. Dengan dukungan aktivitas-aktivitas pendukung (supporting activity), aktivitas utama dapat menjalankan fungsinya dengan baik dalam memaksimalkan nilai pelanggan. Integrasi sub-sub system dalam rangkaian system (SOP) memangkas atau mengeliminasi aktivitas-aktivitas yang berulang tanpa memberi manfaat (tumpang tindih) dalam operasional perusahaan, karena aktivitas-aktivitas tersebut merupakan aktivitas tidak bernilai tambah.

Hasil pemetaan strategi system informasi menunjukkan ketergantungan dan urgenitas system informasi dalam keseluruhan operasional perusahaan (aktivitas utama dan penunjang) penmenunjukkan tingkat ketergantungan yang tinggi dengan tingkat urgenitas yang rendah. Dalam matrik strategi system informasi Warren McFarlan termasuk kedalam kelompok Factory. Ini menunjukkan peran teknologi informasi yang tidak secara langsung memberikan keunggulan kompetitif kepada perusahaan, namun keberadaannya mutlak diperlukan.

Penyusunan Sistem Informasi (SOP) PT. Graha Sarana Gresik, harus mengintegrasikan rantai nilai internal yang tercipta dalam hubungan antara satu bagian dengan bagian lain dalam perusahaan, agar mampu memberikan panduan operasi yang aman, flexible, efektif dan efisien. Disamping itu, walaupun tingkat urgenitas SOP rendah, karena ketergantungan perusahaan terhadap SOP tinggi, perusahaan harus memiliki SOP yang lengkap untuk memberikan kepastian bagi pelaksana dalam menjalankan tugas, tanggung jawab dan wewenangnya.

Hasil penelitian ini dapat menjadi referensi bagi perusahaan dalam memetakan rantai nilai internalnya, menyusun SOP dan memetakan posisi SOP dalam keunggulan bersaing perusahaan. Dibutuhkan penelitian lebih dalam untuk menggali lebih banyak rangkaian rantai nilai internal dalam mengoptimalkan penggunaan sumber daya dan meningkatkan keunggulan bersaing perusahaan. 


\section{DAFT AR PUSTAKA}

Akyar, I., 2012. "Standard operating procedures (what are they good for?)", Intech, pp. 367391. Available: http://cdn.intechopen.com/pdfs-wm/37593.pdf.

Alper Bodur, 2018, The Need For Standard Operation Procedures For Unexpected Events, in International Journal of Advanced Research - January 2018, DOI:10.21474/IJAR01/6181

BarbeÂ B, et al. (2016) The Art of Writing and Implementing Standard Operating Procedures (SOPs) for Laboratories in Low-Resource Settings: Review of Guidelines and Best Practices. PLoS Negl Trop Dis 10(11): e0005053. doi:10.1371/journal.pntd.0005053

Bayangkara IBK, 2019, Audit Manajemen, Prosedur dan Implementasi, Edisi 2, Salemba Empat

Cardiff University (2009). Standard operating procedure for the use or storage of human tissue for the purposes of research or education. Available at: http://www.cf.ac.uk/govrn/cocom/resources/ $\quad$ standard\%20 $\quad$ Operating\%20 procedures.pdf.

Don R. Hansen, Maryanne M. Mowen, 2007, Managerial Accounting, Eighth Edition, Thomson South-Western

F. Warren McFarlan, James L. McKenney, and Philip Pyburn, , 1983, The Information Archipelago-Plotting a Course, Harvard Business Review

Frank, Dave. (2010). How to write SOPs that help increase consistency and improve performance quality in Standard Operating Procedures: A Writing Guide. Available at: http://www.cmmonline.com/ management-training/article/standard-operatingproceduresa-writing-guide.

Hollmann S, et al. (2020) Ten simple rules on how to write a standard operating procedure. PLoS Comput Biol 16(9): e1008095. https://doi.org/10.1371/journal.pcbi.1008095

Institute of Management Accountants (IMA), 1996, Statements on Management Accounting : Value Chain Analysis for Assessing Competitive Advantage, Practice of Management Accounting

Jain, Sanjay Kumar. (2008). Standard operating procedures (SOP) - Back Bone of Pharmaceutical Industries. Pharma info.net Available at: http://www.pharmainfo. net/reviews/standard-operating-procedures-sop-back-bone-pharmaceutical-industries.

Jenni Veronika Br. Ginting, 2015, Peranan Sistem Informasi Dalam Organisasi, Jurnal ilmiah “INTEGRITAS" Vol.1 No. 2 Mei 2015

Josep G. Donelan dan Edward A. Kaplan. 2000. Value Chain Analysis: A Strategic Approach To Cost Management. James M. Reeve. Reading And Issues In Cost Management. Second Edition. Thomson Learning: South - Western College Publishing

Joymalya Bhattacharya, 2015, Guidance for Preparing Standard Operating Procedures (Sops), IOSR Journal Of Pharmacy, (e)-ISSN: 2250-3013, (p)-ISSN: 2319-4219, www.iosrphr.org Volume 5, Issue 1 (January 2015), PP. -29-36 
Levine, David I., \& Toffel, Michael W. (2010). Quality management and job quality: How the ISO 9001 standard for quality management systems affects employees and employers. Journal Management Science, 56(6), 978-96.

Madhav Madhusudan Singh, 2019, What are the SOPs (Standard Operating Procedures) and its benefits ?, publication at: https://www.researchgate.net/publication/337074540

Papp, R. (2001). Strategic Information Technology: Opportunities for Competitive Advantage (pp. 1-24). Hershey PA.

Porter, Michael E.1985. Competitive Advantage. New York: Free Press.

R.H. Schmidt and P.D. Pierce, 2016, The Use of Standard Operating Procedures (SOPs), Handbook of Hygiene Control in the Food Industry. DOI: http://dx.doi.org/10.1016/B9780-08-100155-4.00016-9

Rifka. (2017). Step by Step Lancar Membuat SOP. Yogyakarta: Huta Publisher.

Saxena, Akanksha, 2005, SOP Writing for Clinical Trials: Staff Training Aspects. International Biopharmaceutical Association Publication. Available at: http://www.ibpassociation.org/ IBPA articles/sop writing.htm

Shank, John K., and V. Govindarajan. 1993. Strategic Cost Management. New York: Free Press.

World Health Organization (WHO). Laboratory Quality Management System Handbook. 2011. Geneva: $\mathrm{WHO}$; 2011. http://apps.who.int/iris/bitstream/10665/44665/1/9789241548274_eng.pdf 